\title{
RELATIONSHIP BETWEEN MONOAMINE OXIDASE ACTIVITY AND SEX HORMONE CONCENTRATION IN HUMAN BLOOD PLASMA
}

\author{
MICHAEL BRIGGS AND MAXINE BRIGGS
}

Department of Biochemistry, University of Zambia, P.O. Box 2379, Lusaka, Zambia

\section{(Received 18th Fanuary 1972, accepted 24th Fanuary 1972)}

\begin{abstract}
Summary. The activity of MAO and the concentrations of various sex hormones were determined in blood plasma from healthy men and women and from pregnant women in the third trimester. The enzyme activity is greater in plasma from men than from women at the time of ovulation, but not during the luteal phase. The activity is unchanged during pregnancy. Plasma MAO activity is significantly negatively correlated with testosterone concentration in men and with oestradiol concentration in women. During the luteal phase, the activity is positively correlated with the progesterone : oestradiol ratio of plasma. Enzyme activity is significantly reduced in plasma from women taking oral contraceptive preparations, but not from women receiving depot MPA as a contraceptive. Oral doses of MPA or hydrocortisone had no significant effect on plasma MAO activity in men.
\end{abstract}

Human blood plasma contains a soluble enzyme which catalyses the oxidation of a range of primary amines to the corresponding aldehydes (McEwen \& Cohen, 1963). Plasma monoamine oxidase (MAO) is distinct from ceruloplasmin, histaminase and diamineoxidase (McEwen \& Cohen, 1963; McEwen 1964). It has been extensively purified by McEwen (1965).

For healthy men, it has been claimed (Klaiber, Broverman \& Kobayashi, 1967) that plasma MAO activity is negatively correlated with 24-hr urinary 17-oxosteroid excretion. For healthy women, plasma MAO activity is lowest at the time of ovulation, when oestrogen production is greatest, but activity increases during the luteal phase when progesterone is secreted (Abraham \& Klaiber, 1970). Amenorrhoeic women have elevated plasma MAO activity, which can be reduced by the oral administration of conjugated oestrogens. If oral medroxyprogesterone acetate (MPA) is given simultaneously with the oestrogens, the enzyme activity is not reduced (Vogel, Broverman \& Klaiber, 1971).

In rats, MAO activity both in the blood plasma and in the liver is reduced by oestrogen or androgen administration, and increased by castration (Wartman \& Axelrod, 1963; Billewicz-Stankiewicz \& Ambroziak, 1965). These observations suggest that both oestrogens and androgens can inhibit plasma MAO activity, and that both progesterone and the synthetic progestagen MPA can prevent the inhibitory action of oestrogens. We have, therefore, measured the 
MAO activity of blood plasma collected from groups of healthy men and women and determined the concentrations of steroid hormones in the same specimens. We have also investigated the plasma MAO activity of subjects treated with various synthetic hormone preparations.

Blood was collected by venepuncture into heparinized tubes and plasma was separated and preserved in a deep-freeze. Tests indicated no loss of MAO activity in plasma stored in this manner when compared to that in freshly collected plasma.

Plasma MAO activity was determined by the tyramine oxidation method of Tufvesson (1969). Testosterone, oestradiol and progesterone were measured by competitive protein-binding methods (Diczfalusy \& Diczfalusy, 1970), modified in this laboratory (Briggs, 1972).

Several groups of subjects were investigated. Group A consisted of twentyfour healthy men, and Group B of thirty-one healthy women. Two blood specimens were collected from most of Group B; the first on Day 14 of the menstrual cycles and the second on Day 20 to 23 during the luteal phase. Sixteen pregnant women in the third trimester comprized Group C. Group D was eighteen healthy women taking combined-type oral contraceptive preparations and blood was collected during the second half of their artificial cycles. Group E consisted of nine healthy women receiving intramuscular MPA as a depot-contraceptive. Finally, Groups F and $G$ were the same seven healthy young men who were given a single oral dose of MPA $(40 \mathrm{mg})$, followed 7 days later by a single oral dose of hydrocortisone $(20 \mathrm{mg})$. On each occasion, blood was taken before ingestion of the hormone and again after $6 \mathrm{hr}$.

All subjects were in the age-range 18 to 34 years and none had any present signs, or past history, of any condition thought likely to influence either plasma MAO activity or steroid hormone concentrations. No other pharmaceuticals were taken by any subject for at least 7 days before the collection of the blood specimens.

The values for MAO activity and steroid hormone concentrations in blood plasma are given for the seven groups of subjects in Tables 1 and 2. Plasma hormone levels were not measured for the pregnant women, nor for any of the subjects receiving exogenous hormones.

A consideration of the results shows clearly that plasma MAO activity was significantly higher $(P<0.001)$ in men than during the middle of the menstrual cycle in women. However, during the luteal phase, the mean enzyme activity was not significantly different from the male values. It will be noted that the major hormone change between the two results for women was the large increase in plasma progesterone. The activity of MAO in plasma from the pregnant women was not significantly different from the results for men or for women during the luteal phase.

For women taking oral contraceptive preparations, plasma MAO activity was greatly reduced $(P<0.001)$ but for women receiving depot-contraceptives, the activity was not significantly different from the values for untreated women during the luteal phase.

Oral MPA and hydrocortisone were both without effect on plasma MAO activity in men. 
Our findings are confirmatory of the previously published studies already mentioned. Both natural and synthetic oestrogens suppress the activity of plasma MAO, but their action is antagonized by progesterone, though apparently not by the progestagen component of the oral contraceptives.

\section{TABLE 1}

PLASMA MAO AGTIVITY AND SEX HORMONE CONGENTRATIONS IN UNTREATED MEN AND WOMEN

\begin{tabular}{|c|c|c|c|c|}
\hline \multirow[b]{2}{*}{ Group } & \multirow{2}{*}{$\begin{array}{l}\text { MAO activity } \\
(\mu U / 100 \mathrm{ml})\end{array}$} & \multicolumn{3}{|c|}{ Sex hormone concentrations } \\
\hline & & $\begin{array}{l}\text { Testosterone } \\
(\mathrm{ng} / \mathrm{ml})\end{array}$ & $\begin{array}{l}\text { Oestradiol } \\
(p g / m l)\end{array}$ & $\begin{array}{l}\text { Progesterone } \\
\quad(n g / m l)\end{array}$ \\
\hline $\begin{array}{l}\text { A } \\
\text { B (mid-cycle) } \\
\text { B (luteal phase) } \\
\text { C }\end{array}$ & $\begin{array}{l}791 \pm 155 \\
642 \pm 175 \\
748 \pm 168 \\
725 \pm 186\end{array}$ & $\begin{array}{l}6 \cdot 6 \pm 1 \cdot 7 \\
0 \cdot 4 \pm 0 \cdot 15 \\
0 \cdot 4 \pm 0 \cdot 18 \\
\quad \text { ND }\end{array}$ & $\begin{array}{c}23 \pm 9 \\
158 \pm 35 \\
131 \pm 29 \\
\text { ND }\end{array}$ & $\begin{array}{c}0.45 \pm 0.21 \\
0.61 \pm 0.25 \\
14.90 \pm 8 \cdot 55 \\
\text { ND }\end{array}$ \\
\hline
\end{tabular}

For abbreviations, see text. Results expressed as Means \pm S.D. $\mathrm{ND}$, not determined.

TABLE 2

PLASMA MAO ACTIVITY IN HORMONETREATED MEN AND WOMEN

\begin{tabular}{l|c}
\hline \multicolumn{1}{c|}{ Group } & $\begin{array}{c}M A O \text { activity } \\
(\mu U / 100 \mathrm{ml})\end{array}$ \\
\hline D & $435 \pm 136$ \\
E (before MPA) & $698 \pm 182$ \\
F (after MPA) & $775 \pm 138$ \\
G (before hydrocortisone) & $786 \pm 156$ \\
G (after hydrocortisone) & $778 \pm 145$ \\
& \\
\hline
\end{tabular}

For abbreviations, see text. Results expressed as Means \pm S.D.

To investigate further the effects of sex hormones on MAO activity, we calculated the coefficients of correlation between individual plasma MAO results and oestradiol concentration for the women at mid-cycle, and between MAO activity and testosterone concentration for the men. The results were -0.86 for the women and -0.79 for the men, both of which are highly significant $(P<0.001)$.

It proved more difficult to quantify the protective action of progesterone on the inhibition by oestradiol but, by calculating the ratio, ng progesterone/pg oestradiol for each plasma specimen, the coefficient of correlation between this ratio and the MAO activity for the bloods collected during the luteal phase was +0.56 . This demonstrates that the greater the amount of progesterone per unit of oestradiol, the higher the activity of MAO.

Our results indicate that a major factor determining plasma $\mathrm{MAO}$ activity is the concentration of male and female sex hormones. It has been suggested 
(Klaiber et al., 1967) that plasma MAO activity is an indirect measure of brain MAO activity, but this is open to the objection that the substrate specificities of the two enzymes appear to be different (Blaschko, 1961; McEwen, 1965). However, the plasma MAO changes are similar to the MAO activity of the uterine endometrium, where the highest values are seen in the luteal phase (Grant \& Pryse-Davies, 1968).

There is evidence from other work that brain MAO may be influenced by sex hormones. The highest MAO activity in the brain is seen in the hypothalamus (Zolovick, Pearse, Boehlke \& Eleftheriou, 1966), which is known to possess receptors for sex hormones. In rats, the activity of brain MAO varies considerably with the oestrous cycle, being lowest during dioestrus, then progressively increasing to a maximum at oestrus (Zolovick et al., 1966). If brain MAO is influenced by natural and synthetic sex hormones in the same way as the plasma enzyme, then this would offer a method of investigating differences in brain function between individuals with different hormone production rates, as well as in persons receiving exogenous hormones, such as oral contraceptives.

This work was conducted as a part of International Atomic Energy Agency contract 1006/RB.

\section{REFERENCES}

Abraham, G. E. \& Klaiber, E. L. (1970) Plasma immunoreactive estrogens and LH during the menstrual cycle. Am. 7. Obstet. Gynec. 108, 528.

Billewicz-Stankiewicz, J. \& Ambroziak, T. (1965) Adrenaline oxidase of blood plasma. II. In vivo effect of hormones. Acta physiol. pol. 16, 689.

Blaschko, H. (1961) Amine oxidases. In: The Biochemist's Handbook, p. 373. Ed. C. Long. E. \& F. N. Spon, London.

BrigGs, M. H. (1972) Simple routine methods for the determination of steroid hormones in blood plasma. Med. F. Zambia, (In press).

Diczfalusy, E. \& Diczfalusy, A. (1970) Steroid assay by protein binding. Periodica, Copenhagen.

Grant, E. C. G. \& Pryse-Davies, J. (1968) Effect of oral contraceptives on depressive mood changes and on endometrial monoamine oxidase and phosphatases. Br. med. F. iii, 777.

Klaiber, E. L., Broverman, D. M. \& Kobayashi, Y. (1967) The automatization cognitive style, androgens and monoamine oxidase. Psychopharmacologia, 11, 320.

McEwan C. M. (1964) Serum amine oxidase in pregnancy. F. Lab. clin. Med. 64, 540.

MaEwan C. M. (1965) Human plasma monoamine oxidase. I. Purification and identification. 7. biol. Chem. 240, 2003.

MaEwan, C. M. \& Cohen, J. D. (1963) An amine oxidase in normal human serum. F. Lab. clin. Med. 62,766 .

Turvesson G. (1969) Determination of monoamine oxidase activity in human blood serum with ${ }^{14}$ C-labelled substrates. Scand. 7. clin. Lab. Invest. 23, 71.

Vogel, W., Broverman, D. M. \& Klaiber, E. L. (1971) EEG responses in regularly menstruating women and in amenorrheic women treated with ovarian hormones. Science, N.Y. 172, 388.

WARTMAn, R. J. \& Axelrod, J. (1963) Sex steroids, cardiac norepinephrine and tissue monoamine oxidase levels in the rat. Biochem. Pharmac. 12, 1417.

Zolovick, A. J., Pearse, R., Boehleke, K. W. \& Elefthertou, B. E. (1966) Monoamine oxidase activity in various parts of the rat brain during the estrous cycle. Science, N.Y. 154, 649. 